\title{
Sex reversal, growth, and survival in the guppy Poecilia reticulata (Cyprinodontiformes: Poeciliidae) under laboratory conditions
}

\author{
A. A. Ortega-Salas, H. Reyes-Bustamante and H. Reyes B. \\ Instituto de Ciencias del Mar y Limnología, UNAM. Calz. Joel M. Camarena s/n Apdo. Post. 811, Mazatlán 82040, México; \\ ortsal@ola.icmyl.unam.mx
}

Received 23-X-2012 Corrected 30-I-2013 Accepted 11-VI-2013

\begin{abstract}
Just like it is important to obtain robust and heavy fish in short periods in aquaculture, in aquariology it is important to efficiently obtain colorful fish, which are usually males, and this makes sex reversal important. We studied sex reversal and growth for 120 days in 10-gallon tanks, without aeration, with densities of 1 fry per liter. Temperature varied between 28,2 and $28,7^{\circ} \mathrm{C}$. The $\mathrm{pH}$ was 8,1 to 8,8 and oxygen concentration 6,2 to $6,8 \mathrm{mg} / \mathrm{l}$. Aba Api-balanced food with $25 \%$ protein was used and three different hormones were added to the treatments: (1) Sten (2) Primoteston and (3) Sostenon 250 . Sex reversal in males was $85,0 \%, 92,5 \%$ and $80,0 \%$ respectively. Fishes with treatments 1 and 3 gained an average of $0,48 \mathrm{~g}$ and $4,2 \mathrm{~cm}$ (with treatment 2: $0,44 \mathrm{~g}$ and $4 \mathrm{~cm}$ ). Survival was $85 \%, 92,5 \%$ and $80 \%$; however, these differences were not significant. The three treatments gave the expected results of sex reversal, growth and survival.
\end{abstract}

\section{KEY WORDS}

Animal feed, population density, hormone supply, aquariums without aeration

\section{RESUMEN}

Así como es importante obtener peces más robustos y con mayor peso en poco tiempo en acuacultura, en acuarología es importante tener peces más vistosos, que generalmente son machos, lo que hace la reversión sexual importante. Estudiamos la reversión sexual y crecimiento durante 120 días en acuarios de 10 galones, sin aireación, las densidades fueron de 1 alevín por litro. La temperatura varió entre 28,2 y $28,7^{\circ} \mathrm{C}$. El valor del pH varió de 8,1 a 8,8 y la concentración de oxigeno de 6,2 a $6,8 \mathrm{mg} / \mathrm{L}$. Alimento balanceado Api-aba con $25 \%$ de proteína se utilizó y se agregaron tres hormonas diferentes a los tratamientos: (1) Sten, (2) Primoteston y (3) Sostenon. La reversión sexual a machos fue de $85,0 \%, 92,5 \%$ y $80,0 \%$ respectivamente. A los peces con los tratamientos 1 y 3 ganaron un promedio de $0,48 \mathrm{~g}$ de peso y longitud total de $4,2 \mathrm{~cm}$ (con tratamiento 2: $0,44 \mathrm{~g}$ y $4 \mathrm{~cm}$ ). La sobrevivencia fue de $85 \%, 92,5 \%$ y $80 \%$, sin embargo estas diferencias no fueron significativas. correspondientemente. Los tres tratamientos ofrecieron los resultados esperados de reversión sexual, crecimiento y supervivencia.

\section{PALABRAS CLAVE}

Alimento balanceado, densidad poblacional, suministro hormonal, acuarios sin aireación
Sexual reversal involves the production of organisms of a single sex through the application of steroids to offspring, which have not yet defined their gonads (Hernandez, 1989). The induction of sex reversal in fish is one of the aspects that have been developed mainly in China, Thailand, Israel, Japan and Singapore, countries that have achieved not only scientific benefits, but also have created a large infrastructure in fish farming, allowing generation of large numbers of jobs (Cabeza, 1995).

Sexual dimorphism between males and females of Poecilia reticulata (Peters, 1859) is well defined, and males are the ones that develop more attractive shapes and colors and are reaching higher prices in markets; conditions that justify the production of unisexual populations of males for sale in aquariums or use them as educational material (Axelrod, 1993).

The process of sexual differentiation in the teleost fishes is labile and diverse, it is possible to obtain sexual reversion with the application of steroids in several species gonocoristics and in some hermaphrodite (Francis, 1992). It is important to identify the labile period in which the gonad can be influenced by hormones to successfully 
achieve the sexual reversal (Cabeza, 1995). The administration of androgens during this critical period can reverse completely the fry population or at least more males. The most convenient and effective method is the oral administration of hormones into food to fry, 3 or 4 weeks after hatching when juveniles measure less than 18 to $20 \mathrm{~mm}$ in length; sex is very unstable shortly after hatching and may be affected by internal and external factors. The administration of androgens during this period critical can reverse completely the fry population or at least to have more males. The most convenient and effective method is the oral administration of hormones included in feed of fry (Hepher \& Pruginin, 1985).

In this study in order to perform sexual reversion, calculate growth and survival rate, hormones are directly applied to the offspring, through food in three different treatments

\section{MATERIAL AND METHODS}

The study was conducted in the laboratory of Nutricultivos, Faculty of Sciences of the Sea, Universidad Autónoma de Sinaloa and at the fish hatchery of the Hacienda Xochimancas, Morelos, Mexico; under water, air, and temperature control.

\section{Determination of physicochemical factors}

Physico-chemical samples (temperature, $\mathrm{pH}$ and oxygen) were taken since the introduction of the organisms every 15 days. Temperature was recorded with a thermometer (Broken brand) scale -20 to $110^{\circ} \mathrm{C}$ with an accuracy of \pm 1 digit; $\mathrm{pH}$-was determined with a potentiometer Corning brand with accuracy of \pm 1 digit. Oxygen was determined with an Oximeter model 57 YSI brand.

\section{Determination of biological factors}

Fifty female fish of $P$. reticulata were obtained from "Tropical fish" in Mazatlán, Sinaloa. Transportation was in plastic bags $25 \times 40 \mathrm{~cm}, 30$ of water and supplemented or completed with oxygen. They were placed separately in 10-gallon tanks at a rate of 10 scattered organisms, acclimated and were subsequently treated with a prophylactic bath salt from 3 to 15 minutes. The feeding of fish was with live food (Daphnia magna).

Organisms were placed in 10-gallon aquaria for reproduction, five ovigerous females (6-7 months old) per tank. Water lily was added to protect juveniles against predation. When the young were born, mothers were placed in another aquarium under similar conditions to avoid competition and predation.

\section{Growth and sexual reversal tests}

The growth tests were performed for 120 days in 10-gallon aquaria without aeration. Sampling was carried out with different light mesh nets. The specimens were deposited in Petri dishes, first measured with a hematocytometer (which has divisions of 50, 200 and $1000 \mu \mathrm{m}$ ) and a stereoscopic microscope. When the larvae measured more than $5 \mathrm{~mm}$, we used a Petri and millimeter paper for the same measurement, 1 per liter breeding densities were used, temperature was controlled from 26 to $28^{\circ} \mathrm{C}$ by means of a thermostat. The food consisted of the following diets: pet food Api-aba with $25 \%$ protein added with three different hormones: (1) Sten, (2) Primoteston and (3) Sostenon 250.

Total length (L) and weight (W) were recorded for 120 days. The growth rate of fish in length $(L)$ was obtained by performing a linear regression and the weight (W) with the method of von Bertalanffy (1951).

Development of hormone food: (1) $500 \mathrm{~g}$ of food brand Api-Aba protein $25 \%$, finely ground; (2) $4 \mathrm{~mL}$ of hormone diluted in $300 \mathrm{~mL}$ of ethyl alcohol; (3) mixed evenly, alcohol, hormone and food; (4) drying; and (5) kept in an airtight vials.

\section{Survival}

Survival was recorded daily for 120 days. All tests were initiated with 40 fry at a density of $10 \mathrm{rg} / \mathrm{L}$.

The Kruskal-Wallis analysis was used.

\section{RESULTS}

Temperature varied between 28,2 and $28,7^{\circ} \mathrm{C}$. The $\mathrm{pH}$ varied from 8,1 to 8,8 and the concentration of oxygen varied from 6,2 to $6,8 \mathrm{mg} / \mathrm{L}$.

With treatment 1 the formation of a gonopodium by sexual reversion took between 32 and 40 days, with treatment 2 between 29 and 38 days, and with treatment 3 between 30 and 42 days. They reached $88,2 \%$ sex reversal to male with treatment $1,94,5 \%$ treatment 2 , and $87,5 \%$ treatment 3.

Figure 1 shows the maximum value of growth in length of $P$. reticulata with $4,2 \mathrm{~cm}$ using treatments 1 and 3 , the minimum was $4,0 \mathrm{~cm}$ with treatment 2 during 120 days. The three treatments gave the following line regression Length $(\mathrm{cm})=0,220+0,4853 x$ Fortnight and $R^{2}=0,98$; they grew around $0,48 \mathrm{~cm}$ each fortnight. Figure 2 shows the maximum values of growth in weight of this fish, with $0,48 \mathrm{~g}$ using treatments 1 and 3 , the minimum was $0,44 \mathrm{~g}$ 
with treatment 2 . The von Bertalanffy parameters were as following: $\mathrm{K}=0,1704, \mathrm{~L}_{\infty}=0,62$, and $\mathrm{t}_{0}=-0,8884$ to calculate growth. The three treatments gave the following potential line regression: Weight $=0,5618^{\mathrm{e} 4,1184 \text { Length }} R^{2}=0,9035$

Survival is represented by Figure 4 where treatment 2 have high survival at six fortnight with $58 \%$ than treatment 1 at six fortnight with $31 \%$, and treatment 3 at six fortnight with $21 \%$. After those fortnights survival was steady with treatment 2 thirty seven fish; with treatment 1 thirty four fish and with treatment 3 thirty two fish.

There are not significant differences at $95 \%$ confidence interval.

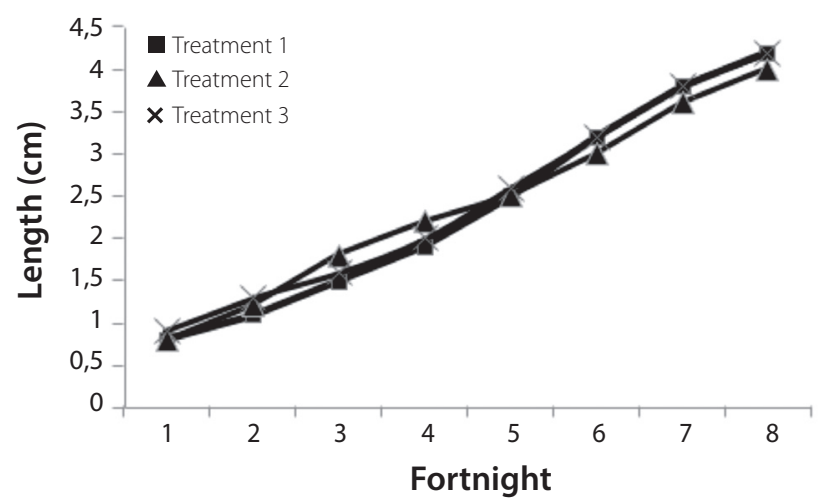

FIG. 1. Growth in length for 8 fortnight's periods.

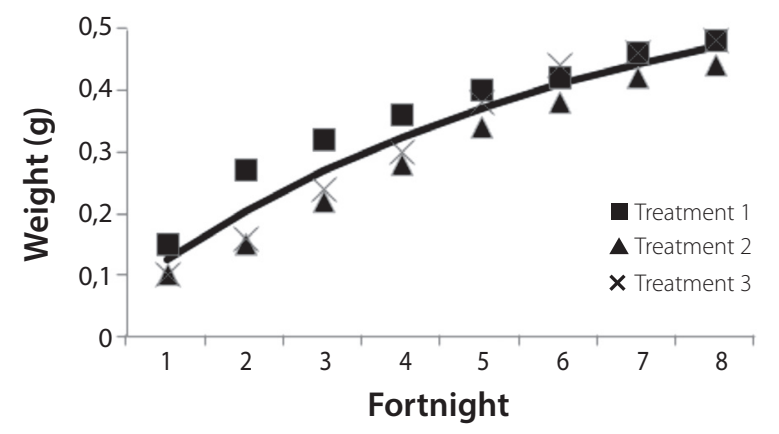

FIG. 2. Growth in weight (g) for 8 fortnight's periods.

\section{DISCUSSION}

The optimum temperature to keep these fish is 20 $30^{\circ} \mathrm{C}$, with a minimum of $18^{\circ} \mathrm{C}$. Axelrod (1993) mentions that the best temperature is about $25,5^{\circ} \mathrm{C}$. Temperature influences on growth and gonadal maturation (Rodríguez, 1992). In this paper is $28^{\circ} \mathrm{C}$.

In natural populations, living in very impacted places, the decrease of $\mathrm{pH}$ values have caused mass deaths of fish, in addition to reduction in the rates of individual and population, growth disorders in reproductive capacity, and deformations in the skeleton (Haines, 1981). The $\mathrm{pH}$ values recorded in this work ranged from 8,1 to 8,8 , which

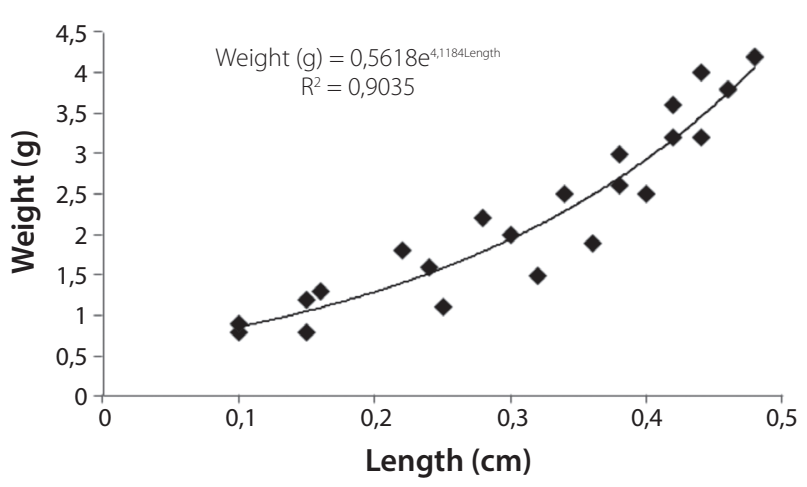

FIG. 3. Weight-length relationship in guppies.

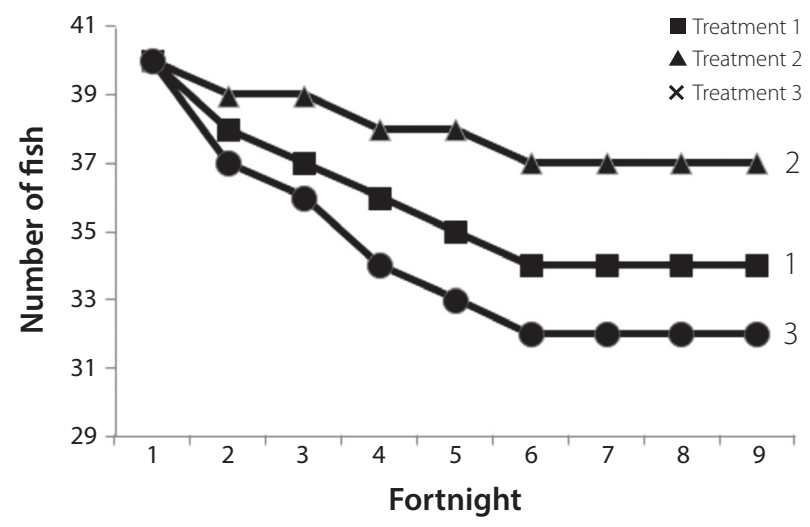

FIG. 4. Survival for 8 fortnight's periods. 
are in the optimal range for the cultivation of this species. Studies of sex reversal in $P$. reticulata, with 17- a-metilestosterone (Takahashi, 1975), 19-nor-etiniltetosterone, 17-betiniltestosterona, 9(11)-dimetiltestosterone and androstenedione (Kavumpurath \& Pandian, 1993) showed that the androstenedine androgen was naturally the most efficient in the sexual reversion. I found that treatment 2 produced similar results with androstenedione at the same rate, even though the methods of application of hormones have been different. The above-mentioned authors applied the hormones gravid females and in this research were applied directly to the young through food and different hormones were used in the three treatments: Primostenon contains testosterone enanthate; $250 \mathrm{mg}$, Sten Propranato testosterone; $20 \mathrm{mg}$, ciclopentil Propianato of testosterone, $75 \mathrm{mg}$ and Dehydroisoandrosterone; $20 \mathrm{mg}$ and Sostenon, Propianato of testosterone; 30mg, Fenilpropianato of testosterone; $60 \mathrm{mg}$, testosterone Isocaproato: $60 \mathrm{mg}$ and testosterone decanoate. In the case of this study, the success of the masculinization may be explained by the fact that the offspring were treated from day one of age, when the gonad begins his training. Maya \& Marañón (2001) mention that high temperatures influence the sex ratio; males reach $34,9 \%$ at $25 \pm 1^{\circ} \mathrm{C}$ and $63,6 \%$ at $31 \pm 1^{\circ} \mathrm{C}$ in native populations.

The survival results for $P$. reticulata appear to be explained by the effects of $\mathrm{pH}$, coinciding with that reported by Haines (1981). Both lower $\mathrm{pH}$ and temperature values cause extension of the period of maturation and sexual differentiation of 1 to 2 weeks. Maya \& Marañón (2001) calculated a survival between 91 and 100 in 60 days; in the present study we obtained between 42 and 79 in 95 days, applying hormones.

Reynolds \& Gross (1992) found that large fathers sired both sons and daughters with higher growth rates and larger daughters resulted in large reproductive output because of large body size.

The results obtained in this research show that it is possible to use of steroids for the production of a unisexual population as an alternative strategy to aquaculture with ornamental fish and especially with $P$. reticulata.

\section{ACKNOWLEDGEMENTS}

We thank A. Nuñez P. and S. Rendón R. for technical support.

\section{REFERENCES}

Axelrod, H. R. (1993). Crianza de los peces de ornato. Hispano Europea: España.

Bertalanffy, L. von. (1951). Theoretische Biologie - Zweiter Band: Stoowechsel, Wachustum.

Cabeza, M. (1995). Hormonas y reproducción. México: Universidad Autónoma Metropolitana.

Francis, C. (1992). Sexual lability in teleost: developmental factors. Quarterly Review of Biology, 67, 1-17.

Haines, T. (1981). Acid precipitation and its consequences for aquatic ecosysterns: a review. Transactions of the American Fisheries Society, 110(6), 669-707.

Hepher, B., \& Pruginin, Y. (1985). Cultivo de peces comerciales. México: Editorial Limusa.

Hernández, B. S. (1989). Uso de hormonas en la reproducción de peces. México: Ed. Fondepesca, Sepesca.

Kavumpurath, S., \& Padian, T. (1993). Masculinization of Poecilia reticulata by dietary administration of synthetic or natural androgen to gravid females. Aquaculture, 116, 83-89.

Maya, P. E., \& Marañón, H. S. (2001). Efecto de la temperatura sobre la proporción sexual de Poecilia reticulata Peters, 1859 (Pisces: Poecilidae). Hidrobiológica, 11(2), 157-162.

Rodríguez, G. M. 1992. Técnicas de evaluación cuantitativa de la madurez gonádica en peces. Chapingo. Serie Ciencias Forestales y del Ambiente, 3(1), 15-21.

Reynolds, J. D., \& Gross, M. R. (1992). Female mate preference enhance offspring growth and reproduction in fish, Poecilia reticulate. Proceedings of the Royal Society of London, 250, 57-62.

Takahashi, H. (1975). Masculinization of gonad of juvenile guppy, Poecilia reticulata, induced by 11 -Ketot stosterona. Bulletin. Faculty Fisheries Hokkaido University, 26(6), 11- 22. 